\title{
Influence on the Properties of Concrete Containing Steel Fibers and Alccofine
}

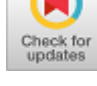

\author{
Akula Rajani, Kurendha Geetha
}

\begin{abstract}
Innovative materials are required in the field of concrete technology for the better construction of the structure. The innovative concrete should have better durability and good aesthetical appearance. The present investigation is aimed at achieving high performance, better and more authentic and uniform quality. In this paper, the effect of Alccofine and conjointly Alccofine and steel fibers, on the mechanical properties of concrete has been evaluated after the curing period of 28 and 56 days. The percentage replacement of Alccofine were adopted as $5 \%, 10 \%$ and $15 \%$ and $1 \%$ steel fibers were added by mass of concrete. Results showed that compressive and flexural strength increased with an increase in Alccofine percentage. It was also observed that concrete with steel fibers along with 15\% Alccofine exhibited highest compressive and flexural strength. Thus, the conjoint presence of Alccofine and steel fibers yields better than concrete without admix.
\end{abstract}

Keywords: Alccofine, Concrete mechanical stability, steel fibers.

\section{INTRODUCTION}

Concrete is the most widely pre-owned construction material due to its adroit and low maintenance cost. Production of Portland cement, which is an important component of concrete, releasing significant amount of $\mathrm{CO}_{2}$, a green house gas [1]. Nowadays, comprehensive efforts are putting to lessen the pollution using industrial wastages as substitution of binder [2]. In the present investigation, a new generation material Alccofine has been adopted. Hence an attempt has also been made in the investigation by incorporating steel fibers in presence of Alccofine. Alccofine a micro-fine material, obtained through the process of control granulation [3]. Durability parameters of concrete will be improved by its refined pore structure and also reduces permeability [4]. Ansari et al., [5] has investigated by partially substituting cement by Alccofine and fly ash and conducted compressive strength and observed that strength has been increased compared to conventional concrete. Narender et al., [6] had studied the effect of nano silica blended concrete with varying concentrations of fly ash, Alccofine and culminated that

Revised Manuscript Received on May 15, 2020.

* Correspondence Author

Akula Rajani*, Assistant Professor, Department of Civil Engineering, Princeton Instuite of Engineering and Technology for Women, Hyderabad, India. Email: akularajni@gmail.com

Kurendha Geetha, Assistant Professor, Department of Civil Engineering, Princeton Instuite of Engineering and Technology for Women, Hyderabad, India. Email: geethakurendha4@gmail.com

(c) The Authors. Published by Blue Eyes Intelligence Engineering and Sciences Publication (BEIESP). This is an open access article under the CC BY-NC-ND license (http://creativecommons.org/licenses/by-nc-nd/4.0/)
Alccofine with nano silica decreased the setting time and achieved high strength compared to other concrete mixes and also bought cost reduction. Faisal et al., [1] has conducted a study on concrete using varying percentages of Alccofine and glass fibers and culminated that Alccofine increases workability and attains high strength in concrete. Divsholi et al., [7] had studied the properties of concrete by replacing Cement partially with Alccofine and concluded that inclusion of ultra fine slag into concrete leads to the development of strength. Gayathri et al., [3] had studied the durability and cementing efficiency of Alccofine in concrete and reported that by increase in percentage content of Alccofine, the value of cementing efficiency increases. Nainwal et al., [8] has evaluated the performance of concrete containing Alccofine and conducted compressive strength test and concluded that concrete containing Alccofine shows better result than normal concrete. In this paper, investigation has been carried out to find the effect of Alccofine and conjointly Alccofine and crimped circular steel fibers on the properties of concrete.

\section{EXPERIMENTAL METHODOLOGY}

\section{A. Constituent materials}

Ordinary Portland cement of 53 grade was adopted for the present investigation. The water- cement ratio was taken as 0.45 for the preparation of concrete specimens. Fine aggregate and coarse aggregate with specific gravity 2.66 and 2.59 respectively were used in preparation of concrete specimens. Portable water available in laboratory was used for mixing and moist curing throughout the investigation. Alccofine, a supplementary cementitious material is partially replaced with different percentages of cement. Crimped circular steel fiber of aspect ratio 50 was used in the present investigation of $1 \%$ by volume of concrete. The details of percentage replacement of cement with Alccofine and addition of steel fibers are presented in Table I.

Table I: Details concrete mixtures

\begin{tabular}{|c|c|c|c|}
\hline Mix ID & Blending material & $\begin{array}{c}\text { Water } \\
\text { content } \\
\left(\mathrm{kg} / \mathrm{m}^{3}\right)\end{array}$ & $\begin{array}{c}\text { Cement } \\
\text { content } \\
\left(\mathrm{kg} / \mathrm{m}^{3}\right)\end{array}$ \\
\hline A0F0 & OPC & 190 & 422.2 \\
\hline A1F0 & OPC + 5\% Alccofine & 190 & 401.1 \\
\hline A1F1 & $\begin{array}{c}\text { OPC + 5\% Alccofine + 1\% } \\
\text { steel fibers }\end{array}$ & 190 & 401.1 \\
\hline A2F0 & OPC + 10\% Alccofine & 190 & 380 \\
\hline A2F1 & $\begin{array}{c}\text { OPC + 10\% Alccofine }+ \\
1 \% \text { steel fibers }\end{array}$ & 190 & 380 \\
\hline \multicolumn{2}{|l|}{} \\
\hline
\end{tabular}




\section{Influence on the Properties of Concrete Containing Steel Fibers and Alccofine}

\begin{tabular}{|c|c|c|c|}
\hline A3F0 & OPC $+15 \%$ Alccofine & 190 & 359 \\
\hline A3F1 & $\begin{array}{c}\text { OPC }+15 \% \text { Alccofine }+ \\
\text { 1\% steel fibers }\end{array}$ & 190 & 359 \\
\hline
\end{tabular}

\section{B. Preparation of concrete specimens}

Cube specimens, prismatic specimens and cylindrical specimens were prepared for various concrete mixtures as mentioned in Table I i.e. for control mix and concrete mixes containing Alccofine and crimped steel fibers. The specimens prepared were demoulded after 24 hours and were cured for 28 and 56 days. For each concrete mix, three specimens were prepared. After curing period, the concrete specimens were tested for mechanical properties.

\section{Tests conducted}

- Compressive strength test

The compressive strength test was conducted as per IS: 516:1959 after a curing period of 28 and 56 days, on cube specimens of different concrete mixes [9]. Three cubes were prepared for every mix and were tested. The mean value obtained was taken as compressive strength of concrete.

- Flexural strength test

Different concrete mixes containing Alccofine and conjointly Alccofine and crimpled circular steel fibers, Flexural strength test has been performed on the prismatic specimens as per IS: 9399:1979 after the curing period [10]. Three prismatic specimens were prepared for each concrete mix and were tested. The average value obtained was taken as flexural strength of that concrete mix.

- Splitting tensile strength test

Cylindrical specimens of various concrete mixes were tested in a hydraulically operated compression testing machine after 28 and 56 days of moist curing. Three replicate cylinder specimens for each concrete mix were prepared and tested. The average value obtained was considered as the splitting tensile strength of that concrete mix.

\section{RESULTS AND DISCUSSIONS}

\section{A. Compressive strength}

The concrete mixes replaced with Alccofine yielded better compressive strength than conventional concrete irrespective of replaced percentage as observed from Figure.1. It is also seen that, with the increase in Alccofine percentage i.e. from $5 \%$ to $15 \%$, the compressive strength has been increased. The optimum compressive strength is achieved for concrete mix containing 15\% Alccofine. The increase in strength due to increase in Alccofine in concrete may be due to the formation of additional calcium-silicate-hydrate gel due to pozzolonic activity of Alccofine which results in refinement of pore structure.

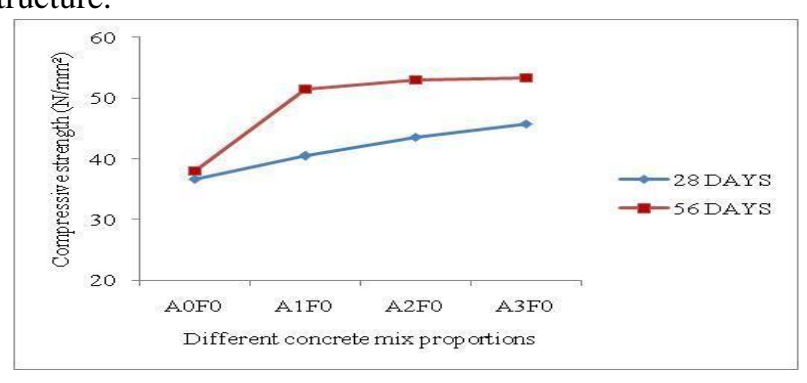

Fig. 1: Compressive strength of concrete

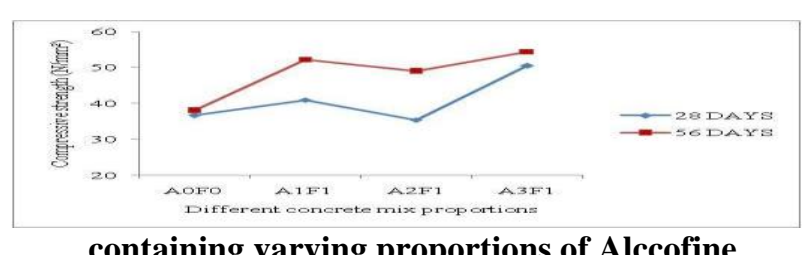

containing varying proportions of Alccofine

Fig. 2: Compressive strength of concrete containing different percentages of Alccofine and 1\% crimpled circular steel fibers

From Fig. 2, it observed that strength increased as the increase in Alccofine up to $5 \%$ and then decreased at $10 \%$ and thereafter increased at $15 \%$ replacement at both the ages i.e., 28 and 56 days. The highest compressive strength is achieved with $15 \%$ Alccofine with $1 \%$ steel fibers. The increase in strength due to the increase in Alccofine content in concrete is mainly due to additional formation of C-S-H gel due to pozzolonic activity of Alccofine which results in pore refinement and also due to crimped circular steel fibers which improved the strength by resisting to cracks. Farther it is also seen that, different concrete mixes with Alccofine and conjointly Alccofine and steel fibers showed higher compressive strength at 56 days as compared to that at 28 days.

\section{B. Flexural strength}

From Fig. 3, it is perceived that flexural strength increases as the percentage replacement of Alccofine i.e. from 5\% to $15 \%$ increased. It is noticed that, concrete specimens made with conjointly Alccofine and steel fibers exhibited better strength than concrete specimens prepared with only Alccofine. Farther from Fig. 4, it is also perceived that flexural strength increases as the percentage of Alccofine in concrete increases and optimum strength was attained for the mix containing 15\% Alccofine and 1\% crimped circular steel fibers. The reason may be due to high fineness of Alccofine and also due the presence of steel fibers which acts as crack arrestor and reduces the internal cracks caused in the tension zone and thereby increasing the flexural strength of concrete

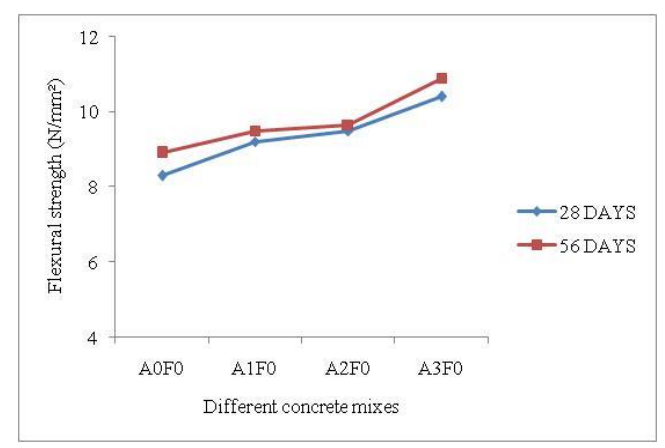

Fig. 3: Flexural strength of concrete containing varying proportions of Alccofine 


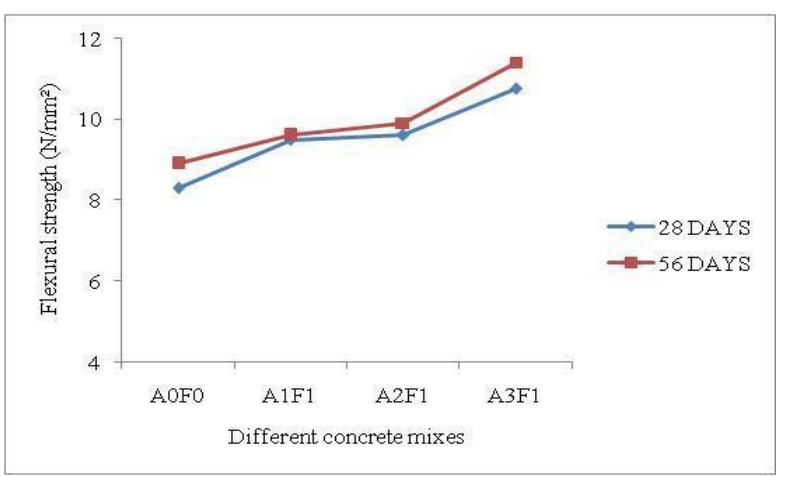

Fig. 4: Flexural strength of concrete containing different proportions of Alccofine and $1 \%$ crimped circular steel fibers

\section{Splitting tensile strength}

From Fig. 5, it is perceived that concrete replaced with Alccofine yielded high tensile strength than conventional concrete at both the ages of curing. Farther it is also seen that, the concrete mix containing $10 \%$ Alccofine along with $1 \%$ steel fibers exhibited higher splitting tensile strength as compare to $5 \%$ and $15 \%$ Alccofine replaced concrete.

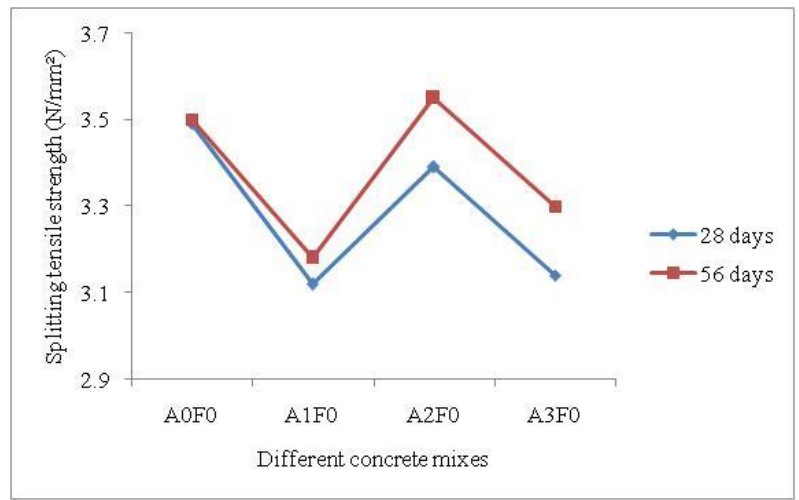

Fig. 5: Splitting tensile strength of Alccofine containing various percentages of Alccofine

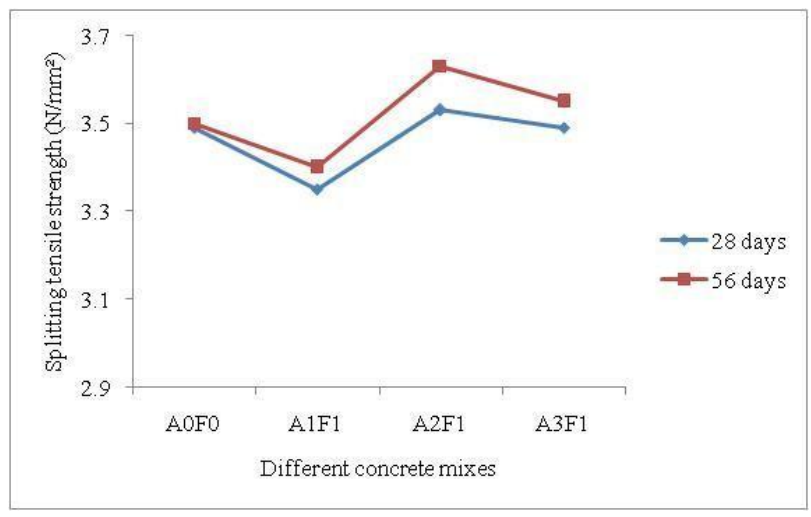

Fig. 6: Splitting tensile strength of concrete containing varying percentages of Alccofine and $1 \%$ crimped circular steel fibers

\section{CONCLUSION}

1. Compressive strength of concrete containing Alccofine yielded maximum strength compared to conventional concrete.
2. Compressive strength of concrete mix containing varying percentages of Alccofine incorporated with crimped circular steel fibers is higher than conventional concrete and concrete with only Alccofine.

3. The concrete containing 15\% Alccofine exhibited highest compressive strength and showed $40 \%$ greater compared to strength of conventional concrete.

4. Flexural strength was found optimum for concrete mix containing high content of Alccofine and steel fibers i.e. 15\% Alccofine and $1 \%$ crimped steel fibers at both the curing periods.

5. The splitting tensile strength of concrete, when replacing cement with Alccofine was found to be increased at later curing ages than initial ages. The concrete specimens made with $10 \%$ Alccofine along with $1 \%$ crimped steel fibers showed highest splitting tensile strength.

\section{REFERENCES}

1. Faisal, K. M. (2016). "Effect of glass fiber on Alccofine mix concrete" International Journal of Scientific \& Engineering Research, 7(10), 31-35.

2. Krishnaraj, L., Madhusudhan, N., and Ravichandran, P. T. (2017). "Experimental study of Ultra fine particles in mechanical and durability properties of Fly Ash cement composite mortar." ARPN Journal of Engineering and Applied Sciences, 12(7), 2297-2305.

3. Gayathri, K., Ravichandran, K., and Saravanan, J. (2016). "Durability and Cementing Efficiency of Alccofine in Concretes" Internationa Journal of Engineering Research \& Technology, 5(05), 460-468.

4. Gupta, A. K. (2018). "Experimental investigation to find the optimum dose of steel fibers in concrete incorporating ultra fine slag" Journal of Engineering Science and technology, 13(1), 187-195.

5. Ansari U.S, Chudhri I.M., Ghuge N.p., P. R. R. (2015). "Concrete with alccofine \& flyash an economical and environmental friendly approach". International journal of modern trends in engineering and Research, 2(4), 226-232.

6. Reddy, A. N., and Meena, P. T. (2018). "Study on effect of colloidal Nano silica blended concrete under compression" International Journal of Engineering \& Technology, 7(1), 210- 213.

7. Lim, D. T. Y., Divsholi, B. S., Kondraivendhan, B., and Teng, S. (2011). "Effect of ultra fine slag replacement on durability effect of ultra fine slag replacement on durability" $36^{\text {th }}$ Conference in Our World in Concrete \& Structures, August 14-16.

8. Nainwal, A., Chauhan, A., and Bhandari, J. (2017). "Comparison between Simple Concrete Cubes and Alccofine Mixed Concrete Cubes (M20 Grade)" International Journal of Scientific Research and Education, 05(09), 6857-6861.

9. IS: 516-1959 Method of tests for strength of concrete.

10. IS: 9399-1979 Specification for apparatus for flexural testing of concrete.

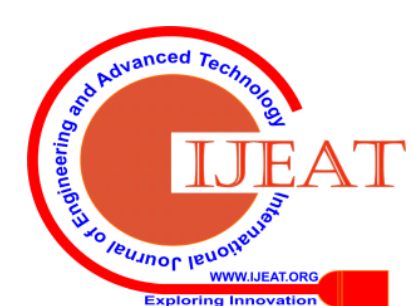


Influence on the Properties of Concrete Containing Steel Fibers and Alccofine

\section{AUTHORS PROFILE}

Akula Rajani, Assistant professor, Department of Civil Engineering, Princeton instuite of Engineering and Technology for Women, Chowdaryguda Village,

Ghatkesar mandal, Medchal Dist.

Telangana-500088.,

Email: akularajni@gmail.com

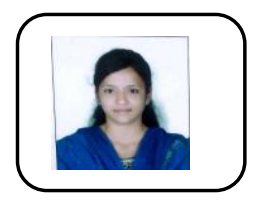

Kurendha Geetha, Assistant professor, Department of Civil Engineering, Princeton instuite of Engineering and Technology for Women, Chowdaryguda Village, Ghatkesar mandal, Medchal Dist. Telangana-500088.

Email: geethakurendha4@gmail.com 